\title{
Microsporogenesis of Apricot Cultivars in Hungary
}

\author{
Veronika HAJNAL ${ }^{*}$, ZarifOMID¹, Márta LADÁNYI², Magdolna TÓTH ${ }^{1}$, László SZALAY \\ ${ }^{1}$ Corvinus University of Budapest, Department of Pomology, 29-43 Villányi út, Budapest, Hungary; veronika.hajnal@uni-corvinus. \\ hu("corresponding author),eng.zarifomid@gmail.com,magdolna.toth@uni-corvinus.hu,laszlo.szalay@uni-corvinus.hu \\ ${ }^{2}$ Corvinus University of Budapest, Department of Mathematics and Informatics, 29- \\ 43 Villányi út, Budapest, Hungary; marta.ladanyi@uni-corvinus.hu
}

\begin{abstract}
Like all phenological processes, microsporogenesis is mainly determined genetically, but its phenotypical expression is greatly influenced by environmental factors, particularly the temperature. During the 3-year experimental period, the process of microsporogenesis was examined in eight apricot cultivars originated in North America and in Romania. The Hungarian cultivar 'Gönci magyar kajszi' was used as the control. Based on the results it was possible to rank the cultivars in terms of their microsporogenesis schedule. The same order was found in all three years. This order also indicates the yield reliability of the cultivars. Endodormancy ended between January $10^{\text {th }}$ and $25^{\text {th }}$ in the buds of the earliest cultivar 'Pinkcot', but not until February $5-10^{\text {th }}$ in the latest cultivar 'Harlayne'. Three of the cultivars had faster flower bud development than the control, in the order 'Pinkcot,' 'Orange Red' and 'Harcot'. Growing these cultivars thus involves greater risk than for 'Gönci magyar kajszi' in Hungary, due to their rapid winter flower bud development. Some cultivars found to have slower flower bud development than 'Gönci magyar kajszi'; 'Litoral,' 'Harogem,' 'Comandor', 'Sirena' and 'Harlayne' - thus these cultivars can be grown more reliably.
\end{abstract}

Keywords: anthers, ecodormancy, endodormancy, flower bud development, Prunus armeniaca L.

\section{Introduction}

The flower bud development of apricot cultivars during the winter dormancy period can be monitored by examining microsporogenesis. Like all phenological processes, microsporogenesis is mainly determined genetically, but its phenotypical expression is influenced to a great extent by environmental factors, particularly by temperature.

Detailed analyses were made in orchards in the Mediterranean region on the microsporogenesis of the most widely grown apricot cultivars (Andreini et al., 2012; Bartolini and Viti, 1999; Bartolini et al., 2006a, 2006b; Julian et al., 2009, 2011; Scalabrelli et al., 1991; Viti and Monteleone, 1991). In Hungary, Banainé (1981) and Nyujtó and Banainé (1975) were the first to publish similar research on Hungarian-bred cultivars. Later, in addition to Hungarian cultivars, foreign cultivars were also examined from this point of view in Hungarian orchards (Németh $e t$ al., 2009; Sebők, 1993; Szalay, 2001; Szalay and Németh, 2010; Szalay et al., 1999; Szalay et al., 2004; Szalay et al., 2006a, 2006b).

All in all, the results achieved till now show that the rate of microsporogenesis differs greatly from one apricot genotype to the other, while there are also considerable differences among locations and years.

Hungary is close to the northern limit for the cultivation of apricot. To ensure reliable yields, it is thus important to choose cultivars with slow winter flower bud devel- opment and a long endodormancy period (Szalay, 2001, 2008).

Efforts are constantly made to discover marketable cultivars with satisfactory yield reliability to extend the list of cultivars suitable to Hungarian conditions.

The microsporogenesis of three Romanian and five North American apricot cultivars was investigated in three consecutive years in the gene bank collection. The main aim was to determine whether the flower bud development traits of these cultivars made them suitable for reliable production under the ecological conditions in Hungary.

\section{Materials and methods}

The experiments were carried out in the Gene Bank Collection of Apricot Cultivars in the Experimental Orchard of the Department of Pomology, Corvinus University of Budapest, which is located in Soroksár, on the outskirts of Budapest.

Experiments were performed in the winters of three consecutive years, 2010/11, 2011/12 and 2012/13, on three cultivars from Romania (Ro) and five from North America (Am). These were as follows: 'Comandor' (Ro), 'Harcot' (Am), 'Harlayne' (Am), 'Harogem' (Am), 'Litoral' (Ro), 'Orange Red' (Am), 'Pinkcot' (Am) and 'Sirena' (Ro). The cultivar 'Gönci magyar kajszi' was included as a control. 


\section{Experimental methods}

Fruiting branches were collected from designated trees every week (or if necessary, several times a week) throughout the winter dormancy period, and the flower buds located on the spurs were examined. The anthers were removed from the flower buds, placed on slides, stained with carmine acetic acid and covered with a cover slide. After gentle pressure, the slides were put under a microscope to examine the tissue structure of the anthers. On each occasion anthers from 8-10 flower buds were examined for each genotype. Phenological stages of microsporogenesis and their ratio were registered on each slide. Six developmental stages were distinguished:

(1)Archesporium stage - the tissues in the anthers were still undifferentiated.

(2)String stage (string) - the differentiation of the archespores in the anthers had begun, but the developing pollen mother cells were still stuck together in strings.

(3)Pollen mother cell stage (p. m. cells) - the pollen mother cells in the anthers were fully developed and could be seen separately on the slides.

(4)Tetrad stage (tetrad) - reduction division into four parts had taken place in the pollen mother cells, leading to the presence of tetrads in the anthers.

(5)Microspore stage (msp) - four microspores had formed from each pollen mother cell and could be seen separately in the anthers.

(6)Pollen stage (pollen grains) - pollen grain formation was complete; pollen grains of the shape and pattern characteristic of the genotype could be seen in the anthers.

The process of microsporogenesis can be modelled by sigmoid type functions of form

$$
Y(X)=100 /\left[1+\operatorname{EXP}\left(-s^{*}(X-m)\right)\right]+\varepsilon
$$

where:

$\mathrm{X}$ - denotes the date expressed in Julian day;

$m$ - is the inflexion point of the curve which corresponds to the median (the $50 \%$ quantile);

$s$ - is a velocity factor i.e. the slope of the curve at point

$X=m \quad s / 4 \quad$;

$\varepsilon$ is a normally distributed error term with expected value of zero.

The regression models fitted to the observations were evaluated by their $F$ values, the $t$ values of the parameter estimations together with the explained variances $\left(\mathrm{R}^{2}\right)$ and the significance of all $F, t$ and $\mathrm{R}^{2}$ values was proved $(\mathrm{p}<0.05)$. Normality of the error term was proved by Kolmogorov-Smirnov's test $(\mathrm{p}>0.05)$.

The $50 \%$ quantile of the sigmoid curve of a given stage was considered as the starting date of that stage in case of the stages beginning from string one up to the pollen one, while the start of blooming was expressed as the $5 \%$ quan- tile since the day on which $5 \%$ of the flowers had opened was recorded in the orchards as the start of blooming.

First we compared the three years considering the starting dates of the different phenological stages using repeated measures ANOVA model separately for all phenological stages. Multivariate tests were used to test the significance of the unexplained variances, Wilk's lambda. Since the sphericity assumption was violated, we used Greenhouse-Geisser's correction. Tests of within subjects effects were executed which was followed by Bonferroni's pairwise comparisons. Normality of the error term was proved then by Kolmogorov-Smirnov's test $(p>0.05)$.

To test the similarity of the orders of the cultivars considering the occurrence of the phenological phases, we used Friedman's rank test.

To detect the year dependency, coefficients of variations $(\mathrm{CV})$ were calculated as the standard errors divided by the means of starting dates of phenological stages for each cultivar and phenological stage. The CV data were then compared with 2-way ANOVA model where the two fixed factors were cultivar and phenological stage. Normality of the error term was proved then by KolmogorovSmirnov's test $(p>0.05)$.

We also tested the significance of the differences between the velocity factors of the phenological stages and cultivars with a 2-way analysis of variance model where the fixed factors were again the cultivar and phenological stage and the random factor was the year. Since the normality assumption was violated in this case, we applied an inverse transformation. Normality of the error term was then proved by Kolmogorov-Smirnov's test again ( $\mathrm{p}>$ $0.05)$.

In both ANOVA tests, homogeneity of variances was checked by Levene's test $(p=0.05)$. Post hoc tests were performed by Tukey's or Games-Howell' test, according to the result of test Levene's test.

Statistical analysis was performed using IBM SPSS 20.

\section{Results and discussions}

Substantial differences were observed among cultivars regarding the schedule and the speed of the microsporogenesis process, and large differences were also noted between the years. The starting dates of each phenological stage are taken as the inflexion points of the sigmoid curves from the beginning of ecodormancy up to pollen stage. The start of blooming is taken as the value of 5\% quantile (Tab. 1.). The dates are expressed as Julian days, i.e. the number of days elapsed from January $1^{\text {st }}$.

First we compared the years considering the starting dates of the different phenological stages using repeated measures ANOVA model separately for all phenological stages. Multivariate tests were all significant except for pollen mother cell stage (Wilk's lambda were all under 0.3 with $\mathrm{p}<0.01$ except for pollen mother cell stage when it was as high as 0.95 with $\mathrm{p}=0.83$ ). Since the sphericity 
436

assumption was violated, we used Greenhouse-Geisser's correction ( $\varepsilon$ were all above 0.53 ). Tests of within subjects effects revealed highly significant year effect $\left(\mathrm{F}\left(2^{*} \varepsilon ; 16^{*} \varepsilon\right)\right.$ were all above 20 with $\mathrm{p}<0.01$ except for pollen mother cell stage for which $\mathrm{F}(1.1 ; 8.7)=0.17$ with $\mathrm{p}=0.71)$. Bonferroni's pairwise comparisons yielded that every year was significantly different from all the others for blooming and pollen grains $(p<0.01)$, year 2012 differed significantly $(p<0.01)$ from the more similar ones 2011 and 2013

( $p>0.05)$ in cases of string, tetrads and microspore stage, while, of course, all the three years were similar for pollen mother cell stage $(p>0.99)$.

Tab. 1. Starting dates of the phenological stages in microsporogenesis in apricot cultivars in three consecutive years (number of days from January $1^{\text {st }}$ ) with the velocity factors $(s)$ of the sigmoid curves. The starting dates of each phenological stage are taken as the inflexion points of the sigmoid curves from the beginning of ecodormancy up to pollen stage $(\mathrm{m})$. The start of blooming is taken as the value of $5 \%$ quantile

\begin{tabular}{|c|c|c|c|c|c|c|c|c|c|c|c|c|}
\hline \multirow{2}{*}{$\begin{array}{c}\text { Cultivar/year } \\
2011\end{array}$} & \multicolumn{2}{|c|}{ string } & \multicolumn{2}{|c|}{ p.m.cells } & \multicolumn{2}{|c|}{ tetrads } & \multicolumn{2}{|c|}{ msp } & \multicolumn{2}{|c|}{ pollen grains } & \multicolumn{2}{|c|}{ blooming } \\
\hline & $\mathrm{m}$ & s & $\mathrm{m}$ & s & $\mathrm{m}$ & s & $\mathrm{m}$ & s & $\mathrm{m}$ & s & $\mathrm{m}^{*}$ & s \\
\hline Pinkcot & 25 & 0.25 & 34 & 0.37 & 38 & 0.45 & 47 & 0.66 & 76 & 0.54 & 84 & 1.30 \\
\hline Orange Red & 27 & 0.29 & 35 & 0.35 & 39 & 0.50 & 47 & 0.60 & 78 & 0.61 & 85 & 1.58 \\
\hline Harcot & 30 & 0.29 & 37 & 0.38 & 41 & 0.47 & 49 & 0.50 & 78 & 0.62 & 84 & 1.58 \\
\hline Gönci magyar kajszi & 32 & 0.28 & 40 & 0.37 & 43 & 0.45 & 52 & 0.56 & 79 & 0.57 & 86 & 1.55 \\
\hline Litoral & 34 & 0.29 & 40 & 0.35 & 45 & 0.48 & 53 & 0.47 & 80 & 0.53 & 87 & 1.45 \\
\hline Harogem & 36 & 0.30 & 43 & 0.38 & 48 & 0.50 & 56 & 0.51 & 81 & 0.52 & 91 & 1.45 \\
\hline Comandor & 36 & 0.30 & 43 & 0.38 & 48 & 0.50 & 56 & 0.51 & 81 & 0.52 & 91 & 1.45 \\
\hline Sirena & 38 & 0.30 & 44 & 0.32 & 49 & 0.46 & 57 & 0.50 & 82 & 0.64 & 92 & 1.45 \\
\hline Harlayne & 40 & 0.29 & 46 & 0.32 & 51 & 0.47 & 59 & 0.74 & 84 & 0.56 & 93 & 1.45 \\
\hline 2012 & $\mathrm{~m}$ & s & $\mathrm{m}$ & $s$ & $\mathrm{~m}$ & $s$ & $\mathrm{~m}$ & s & $\mathrm{m}$ & $s$ & $\mathrm{~m}^{*}$ & $s$ \\
\hline Pinkcot & 11 & 0.37 & 24 & 0.37 & 38 & 0.45 & 52 & 0.57 & 73 & 0.69 & 80 & 1.19 \\
\hline Orange Red & 15 & 0.31 & 27 & 0.36 & 39 & 0.46 & 53 & 0.51 & 74 & 0.52 & 82 & 1.09 \\
\hline Harcot & 18 & 0.35 & 32 & 0.39 & 46 & 0.45 & 58 & 0.33 & 76 & 0.75 & 83 & 0.92 \\
\hline Gönci magyar kajszi & 20 & 0.31 & 37 & 0.36 & 51 & 0.47 & 64 & 0.60 & 77 & 0.77 & 83 & 1.95 \\
\hline Litoral & 24 & 0.31 & 42 & 0.35 & 54 & 0.39 & 67 & 0.67 & 79 & 0.76 & 85 & 1.11 \\
\hline Harogem & 28 & 0.31 & 45 & 0.35 & 57 & 0.40 & 70 & 0.57 & 80 & 0.75 & 86 & 1.73 \\
\hline Comandor & 28 & 0.31 & 45 & 0.35 & 57 & 0.40 & 70 & 0.57 & 80 & 0.75 & 86 & 1.73 \\
\hline Sirena & 31 & 0.33 & 48 & 0.34 & 61 & 0.39 & 72 & 0.63 & 81 & 0.70 & 88 & 2.19 \\
\hline Harlayne & 36 & 0.33 & 54 & 0.39 & 66 & 0.54 & 75 & 0.57 & 83 & 0.89 & 89 & 2.19 \\
\hline 2013 & $\mathrm{~m}$ & s & $\mathrm{m}$ & s & $\mathrm{m}$ & s & $\mathrm{m}$ & s & $\mathrm{m}$ & s & $\mathrm{m}^{*}$ & s \\
\hline Pinkcot & 25 & 0.25 & 32 & 0.35 & 37 & 0.45 & 49 & 0.57 & 79 & 0.55 & 100 & 0.98 \\
\hline Orange Red & 29 & 0.27 & 34 & 0.37 & 39 & 0.35 & 50 & 0.64 & 79 & 0.55 & 101 & 0.85 \\
\hline Harcot & 31 & 0.26 & 38 & 0.44 & 42 & 0.59 & 52 & 0.54 & 80 & 0.59 & 102 & 0.74 \\
\hline Gönci magyar kajszi & 33 & 0.24 & 39 & 0.34 & 43 & 0.61 & 53 & 0.54 & 81 & 0.57 & 103 & 0.88 \\
\hline Litoral & 35 & 0.29 & 39 & 0.34 & 45 & 0.41 & 55 & 0.68 & 82 & 0.56 & 103 & 0.76 \\
\hline Harogem & 36 & 0.28 & 42 & 0.37 & 46 & 0.41 & 55 & 0.45 & 82 & 0.56 & 104 & 0.77 \\
\hline Comandor & 36 & 0.28 & 42 & 0.37 & 46 & 0.41 & 55 & 0.45 & 82 & 0.56 & 104 & 0.77 \\
\hline Sirena & 38 & 0.30 & 44 & 0.38 & 48 & 0.45 & 58 & 0.54 & 83 & 0.59 & 104 & 0.64 \\
\hline Harlayne & 41 & 0.31 & 49 & 0.39 & 53 & 0.45 & 61 & 0.56 & 84 & 0.54 & 104 & 0.65 \\
\hline
\end{tabular}


Tab. 2. Coefficients of variations of the starting dates of the stages $(\mathrm{m})$ in microsporogenesis in apricot cultivars with respect to the three years i.e. the standard errors divided by the means which can express the variability of the starting dates of phenological stages, depending on the effect of year. The different letters A to $\mathrm{C}$ represent phenological stages with significantly different $\mathrm{CV}$ values according to Games-Howell's post hoc test $(\mathrm{p}<0.05)$

\begin{tabular}{ccccccc} 
Cultivar & string & p.m.cells ${ }^{\mathrm{BC}}$ & tetrads $^{\mathrm{AB}}$ & $\mathrm{msp}^{\mathrm{AB}}$ & $\begin{array}{c}\text { pollen } \\
\text { grains }\end{array}$ & blooming \\
\hline $\begin{array}{c}\text { Pinkcot } \\
\text { Orange }\end{array}$ & 0.40 & 0.18 & 0.02 & 0.05 & 0.04 & 0.03 \\
$\begin{array}{c}\text { Red } \\
\text { Harcot }\end{array}$ & 0.31 & 0.13 & 0.10 & 0.10 & 0.03 & 0.03 \\
\hline $\begin{array}{c}\text { Gönci } \\
\text { magyar } \\
\text { kajszi }\end{array}$ & 0.26 & 0.09 & 0.06 & 0.09 & 0.03 & 0.04 \\
\hline Litoral & 0.20 & 0.04 & 0.11 & 0.13 & 0.02 & 0.07 \\
\hline Harogem & 0.14 & 0.04 & 0.12 & 0.14 & 0.01 & 0.03 \\
\hline Comandor & 0.14 & 0.04 & 0.12 & 0.14 & 0.01 & 0.03 \\
\hline Sirena & 0.11 & 0.05 & 0.14 & 0.13 & 0.01 & 0.04 \\
\hline Harlayne & 0.07 & 0.08 & 0.14 & 0.13 & 0.01 & 0.02 \\
\hline
\end{tabular}

To detect the year dependency, coefficients of variations $(\mathrm{CV})$ were calculated as the standard errors divided by the means of starting dates of phenological stages for each cultivar and phenological stage. The 2-way ANOVA test revealed that the effect of cultivar was not significant $(\mathrm{F}(8 ; 40)=0.53 ; \mathrm{p}=0.83)$ while the one of phenological stage was significant $(\mathrm{F}(5 ; 40)=13.93 ; \mathrm{p}<0.001)$. The result of Games-Howell's post hoc test is presented in Tab. 2. We can conclude generally that the order of the phenological stages according to their year dependency is: string, microspore stage (msp), tetrads, mother cell stage (p. m. cells), blooming and pollen grains. Moreover, this can be stated quite similarly for the cultivars.

Three stages in microsporogenesis were highlighted to introduce the differences between cultivars and years: the string stage, which indicates the end of endodormancy in the flower buds; the microspore stage, when reduction division is completed and the formation of pollen grains has begun; and the start of blooming, which indicates the end of the microsporogenesis process.

In all three years the flower bud development of 'Pinkcot' was the earliest of all the cultivars, while that of 'Harlayne' was the latest. The microsporogenesis rates of the other cultivars tested, and also of the control cultivar 'Gönci magyar kajszi' (GMK), fell between these values. The results obtained for these three cultivars in 2011 are illustrated in Fig. 1 for the three stages focused (the string stage, the microspore stage and the start of flowering).

The order of the cultivars considering the occurrence of the phenological stages was very similar in each year for each phenological stage (Friedman's test: $\mathcal{X}^{2}(2)<0.4$; $\mathrm{p}>0.8$ ). In a later phenological stage, however, the variance of the starting days measured for different cultivars was mostly lower. The negative linear trend was significant (Pearson's $\mathrm{R}=-0.47 ; \mathrm{p}<0.01$ ). We also proved for string and blooming phases that the later the stage starts in a year the more quickly it passes (Pearson's $\mathrm{R}=-0.38 ; \mathrm{p}<0.05$; Pearson's $\mathrm{R}=-0.67 ; \mathrm{p}<0.001)$.

At the beginning of microsporogenesis each phenological stage takes a longer time to be completed. The development of the string stage from the archespore tissue took 20-24 days in all the cultivars tested, while the transition from the tetrad stage to the microspore stage required 10-14 days and blooming was completed within 3-5 days (Fig. 1).

We can prove this using a two-way ANOVA test of significance for the differences of the velocity factors. We detected that the in heterogeneity of velocity factors was highly significant for the phenological stages $(\mathrm{F}(5 ; 106)$ $=262.94 ; \mathrm{p}<0.001)$ and insignificant for the cultivars $(\mathrm{F}(8 ; 106)=0.43 ; \mathrm{p}=0.90)$. The interaction phenological stage ${ }^{*}$ cultivars was insignificant $(\mathrm{F}(40 ; 106)=0.71 ; \mathrm{p}$ $=0.89)$. Tukey's post hoc test revealed that every single velocity factor of a phenological stage differs significantly from all of others but msp and pollen grains $(\mathrm{p}<0.001$; $\mathrm{p}$ $=0.15$, respectively). We can conclude that the later the start of phenological stage is, the faster its process is, similarly for all cultivars.

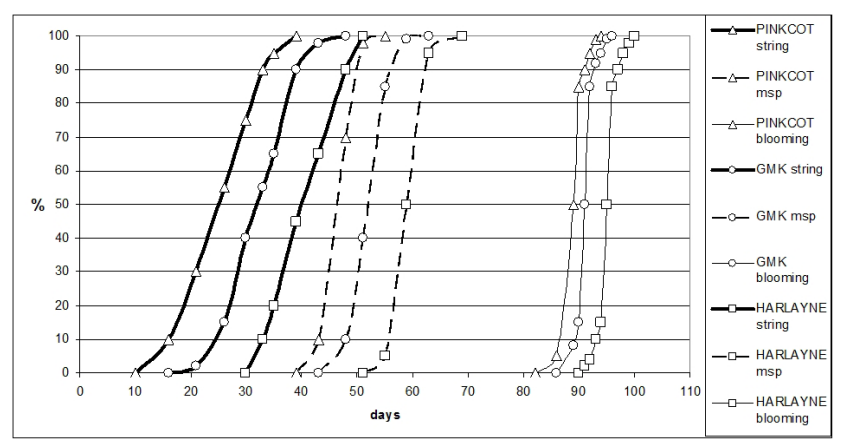

Fig. 1. Start and end of microsporogenesis and the microspore stages for three apricot cultivars ('Pinkot', 'Gönci Magyar kajszi', 'Harlayne') in 2011

The differences between the years are illustrated using the 3-year results recorded for the 'Litoral' cultivar, which has a medium rate of flower bud development (Fig. 2). The end of endodormancy (string stage) in the flower buds of this cultivar occurred on the same day, February $3^{\text {rd }}$, in 2011 and 2013, while in 2012 it was observed 10 days earlier. The time required for each stage of microsporogenesis to develop differed over the years, due to the diverse weather conditions.

In 2011, the microspores developed very quickly after the end of endodormancy in the flower buds of the ' $\mathrm{Li}$ toral' cultivar, the start of the microspore stage being re- 
438

corded on February $22^{\text {nd }}$. Blooming, however, was not the earliest in this year, beginning on March $30^{\text {th }}$, which was intermediate between the other two years.

In 2012, the string stage was reached early, but the microspores developed latest in this year. Nevertheless, at the end of the microsporogenesis process, blooming started earlier than in the other two years, on March $25^{\text {th }}$.

In 2013, the process of microsporogenesis started similarly to that observed in 2011 . The string stage was reached on the same date in 2013 as in 2011 and microspore development started two days later than in 2011. The blooming of 'Litoral', however, was latest in this year, not starting before than April 14 ${ }^{\text {th }}$.

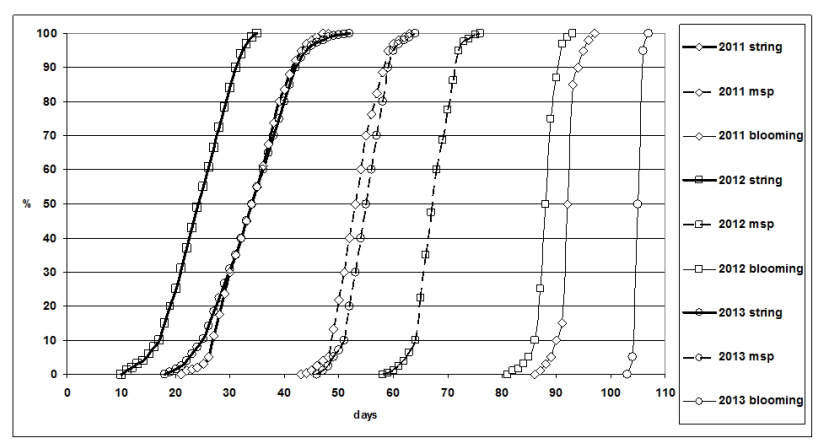

Fig. 2. Occurrence and characteristic of the phenological stages of microsporogenesis in the 'Litoral' cultivar in three consecutive years (2011-2013)

The rate of microsporogenesis is greatly influenced by environmental factors, especially the temperature (Szalay, 2008), resulting in substantial differences among years. This was confirmed by the present studies on nine cultivars over a 3-year period. However, the order of the cultivars was almost the same in each year, suggesting that, like all phenological processes, microsporogenesis is fundamentally genetically determined. This means that even analyses carried out over a few years are sufficient to allow the cultivars to be reliably ranked in terms of the end of endodormancy and the schedule of microsporogenesis. Before new cultivars are introduced into cultivation, it is essential to test their suitability for a given location. The data provided by phenological analysis are useful for this purpose if compared with those of control cultivars having known their frost tolerance and winter hardiness.

There is no close correlation between the schedule of microsporogenesis and the frost tolerance of the overwintering organs in the flower buds, as they are subject to separate genetic regulation (Bassi et al., 2006). However, the length of endodormancy has a considerable influence on the frost tolerance and winter hardiness of the cultivar, as the frost tolerance of the over-wintering organs decrease just during the ecodormancy period (Szalay, 2001, 2008).

As Hungary is one of the most northern countries where apricots can be grown economically, the best cultivars are those in which the over-wintering organs, par- ticularly the flower buds, have slow winter development, while the end of endodormancy is late and frost tolerance is maintained for a long period (Szalay, 2001, 2008). Apricot cultivars with short endodormancy and rapid flower bud development can be successfully cultivated in more southern countries in the Mediterranean region (Guerriero et al., 1988). From the point of view of yield reliability, cultivars with long endodormancy, bred under ecological conditions similar to those in Hungary, could be promising for widening the choice of cultivars. One aim of the apricot breeding programme in Romania was to develop late-flowering cultivars with good frost tolerance and winter hardiness for cultivation in the temperate zone (Cociu, 1982, 1991; Cociu and Hough, 1985). The cultivars examined in the present work originated from this breeding programme. It is planned to continue these tests on the latest cultivars developed by Romanian breeders (Topor $e t$ al., 2010). In Canada, too, an improvement in frost tolerance and winter hardiness is an important aim in apricot breeding (Layne, 1978, 1979, 1981; Layne and Gadsby, 1995). Three cultivars ('Harcot', Harogem', 'Harlayne') originating from the Canadian breeding programme were also included in the present tests.

\section{Conclusions}

Over a three-year period the phenological processes of five cultivars from North America and three from Romania were analysed, using the cultivar 'Gönci magyar kajszi', which has moderate frost tolerance and winter hardiness and is grown widely in commercial orchards in Hungary, as a control. On the basis of the results, the cultivars were ranked in terms of the schedule of microsporogenesis. Almost the same order was observed in all three years, and this order can be regarded as indicative of the yield safety of cultivars. The end of endodormancy in the flower buds was recorded between January $10^{\text {th }}$ and $25^{\text {th }}$ for the firstranking cultivar 'Pinkcot', but not before February $5-10^{\text {th }}$ for the last cultivar, 'Harlayne.' Three of the cultivars tested had faster flower bud development than the control ('Pinkcot', 'Orange Red' and 'Harcot', in this order), indicating that their cultivation would be riskier than that of 'Gönci magyar kajszi' in Hungary, due to their rapid flower bud development in winter. Cultivars found to have slower flower bud development than 'Gönci magyar kajszi' (in the order 'Litoral', 'Harogem', 'Comandor', 'Sirena' and 'Harlayne') could be grown with less risk in Hungary.

\section{Acknowledgement}

The researches were supported by the TÁMOP 4.2.1./ B-09/KMR/2010-0005, VM State Genereservation Tasks Project (Állami Génmegőrzési Feladatok) É-45343 and GOP-1.1.1-09/1-2009-0042. 


\section{References}

Andreini L, Viti R, Bartolini S, Ruiz D, Egea J, Campoy JA (2012). The relationship between xilem differentiation and dormancy evolution in apricot flower buds (Prunus armeniaca L.): the influence of environmental conditions in two Mediterranean areas. Trees 26:919-928.

Banainé B (1981). Kajszi F1 hibridek populációgenetikai értékelése (in Hungarian). Population genetysc evaluation of apricot F1 hibrides. Horticultural University, Budapest, Doctoral thesis.

Bartolini S, Viti R (1999). Histological studies on flower buds of cultivar 'Stark Early Orange'. Acta Hort 488:335-339.

Bartolini S, Viti R, Guerriero R (2006a). Xilem differentiation and microsporogenesis during dormancy of apricot flower buds (Prunus armeniaca L.) European J Hort Sci 71:84-90.

Bartolini S, Viti R, Laghezali M, Olmez HA (2006b). Xilem vessel differntiation and microsporogenesis evolution in 'Canino' cultivar growing in tree different climatic areas. Italy, Marocco and Turkey. Acta Hort 701:135-140.

Bassi D, Bartolini S, Viti R (2006). Recent advences on environmental and physiological challenges in growing apricot. Acta Hort 717:23-31.

Cociu V (1982). New apricot varieties breeded in Romania. Acta Hort 121:211-216.

Cociu V, Hough LF (1985). Germplasm of apricot and some suggestions for its use. Acta Hort 192:291-297.

Cociu V (1991). Forty years of apricot breeding of Romania. Acta Hort 293:197-201.

Guerriero R, Audergon JM, Martinez CA (1988). Apricot cultivars for Mediterranean climate. Acta Hort. 209:39-47.

Julian C, Herrero M, Rodrigo J (2009). Pollen development and chilling requirements in apricot cultivars. Acta Hort 814:417-419.

Julian C, Rodrigo J, Herrero M (2011). Stamen development and winter dormancy in apricot (Prunus armeniaca). Annals of Botany 108:617-625.

Layne REC, Gadsby MF (1995). Determination of cold hardiness and estimation of potential breeding value of apricot germplasm. Fruit Varieties Journal 49(4):242-248.

Layne REC (1978). 'Harcot' apricot. HortScience 13:64-65.

Layne REC (1979). 'Harogem' apricot. HortScience 14:758759.

Layne REC (1981). 'Harlayne' apricot. HortScience 16:97-98.

Németh Sz, Reményi ML, Szalay L (2009). Development of apricot flower buds on different types of fruiting branches. Acta Horticulturae et Regiotecturae 12:89-91.
439

Nyujtó F, Banainé B (1975). Előzetes közlemény a kajszibarack fajták termőrügyei téli morfogenézisének vizsgálatáról (in Hungarian). Preliminary study of winter flower bud morphogenesis of apricot cultivars. Gyümölcstermesztés. 2:1520.

Scalabrelli G, Viti R, Cinelli F (1991). Change in catalase activity and dormancy of apricot buds in response to chilling. Acta Hort 293:267-274.

Sebők Sz (1993). A mikrosporogenézis jelentősége a kajszibarack nemesítési anyagainak megítélésében (in Hungarian). Importance of microsporogenesis in the apricot breeding. Horticultural University, Budapest, $\mathrm{MsC}$ thesis.

Szalay L (2001). Kajszi- és őszibarackfajták fagy- és téltürése (in Hungarian). Cold hardiness and winter tolerance of apricot and peach cultivars. Faculty of Horticultural Sciences, Szent István University, Budapest, $\mathrm{PhD}$ thesis.

Szalay L (2008). Development and cold hardiness of flower buds of stone fruits, p. 63-82. In: Nyéki J, Soltész M, Szabó Z (Eds.). Morphology, biology and fertility of flowers in temperate zone fruits. Academic Press, Budapest. ISBN 978-963-05-8591-0

Szalay L, Pedryc A, Szabó Z (1999). Dormancy and cold hardiness of flower buds of some Hungarian apricot varieties. Acta Hort 488:315-319.

Szalay L, Balázs G, Nagy P (2004). Evaluation of foreign apricot cultivars in Hungary. Intern J Hort Sci 10(3):51-55.

Szalay L, Papp J, Pedryc A, Szabó Z (2006a). Diversity of apricot varieties based on traits determining winter hardiness and early spring frost tolerance of floral buds. Acta Hort 701:131-134.

Szalay L, Pedryc A, Szabó Z, Papp J (2006b). Influence of the changing climate on flower bud development of apricot varieties. Acta Hort 717:75-78.

Szalay L, Németh S, (2010). Phenological process of dormancy in apricot genotypes in the central part of the Carpatian Basin. Acta Hort 862:251-255.

Topor E, Vasilescu R, Balan V, Tudor V (2010). Apricot breeding programme for late and very late ripening period in Romania. Acta Hort 862:137-142.

Viti R, Monteleone P (1991). Observations on flower bud growth in some low yield varieties of apricot. Acta Hort 293:319-326. 